\title{
Effect of Temperature, Electrolyte Composition and Immersion Time on the Electrochemical Corrosion Behavior of CoCrMo Implant Alloy Exposed to Physiological Serum and Hank's Solution
}

\author{
Jéferson Aparecido Moreto ${ }^{a}$, Adriana Costa Rodrigues ${ }^{a}$, Rafaela Rodrigues da Silva Leite ${ }^{b}$, \\ Alexandre Rossi ${ }^{a}$, Luís Antônio da Silva ${ }^{a}$,Valéria Almeida Alves ${ }^{a}$ \\ ${ }^{a}$ Instituto de Ciências Exatas, Naturais e Educação, Universidade Federal do Triangulo Mineiro \\ (UFTM), Avenida Doutor Randolfo Borges Júnior, Univerdecidade, 38.064-200, Uberaba, MG, Brasil \\ ${ }^{b}$ Departamento de Farmácia, Universidade Federal dos Vales do Jequitinhonha e Mucuri, Rodovia \\ MGT 367 - Km 583, 5000, 39100-000, Diamantina, MG, Brasil
}

Received: July 17, 2017; Revised: November 12, 2017; Accepted: February 28, 2018

\begin{abstract}
A new study about corrosion behavior of CoCrMo alloy used as implant material exposed to the physiological serum and Hank's solution in different temperatures, electrolyte compositions and immersion time were simulated, using open circuit potential (OCP), potentiodynamic polarization curves (PPC) and electrochemical impedance spectroscopy (EIS.) From the results, it can be concluded that CoCrMo biomaterial is influenced by electrolyte composition and temperature, and the passive films were more protective when formed in presence of physiological serum. Comparing the $E_{\text {corr }}$ for both solutions, it is possible to verify that the Hank's solution presented values more negative for the two studied temperatures $\left(25\right.$ and $\left.37^{\circ} \mathrm{C}\right)$, indicating a greater susceptibility to the corrosion process. Regarding the results of potentiodynamic polarization, the $i_{\text {pass }}$, decreased as function of time, indicating a more protective passive film at $25^{\circ} \mathrm{C}$. In regards to the physiological serum, the highest $i_{\text {pass }}$ values at $37^{\circ} \mathrm{C}$ evidenced the formation of a less stable passive film. The different behavior of $i_{\text {pass }}$ in Hank's solution may be related to the competitiveness between a possible film of D-glucose and oxides of the alloy metals. EIS studies suggest that the film formed in presence of physiological serum is nobler than that with Hank's solution.
\end{abstract}

Keywords: Passivation current, Global electrochemical techniques, Biomedical application, Corrosion resistance.

\section{Introduction}

Implant materials are usually metallic materials like titanium alloys, Co-based alloys and austenite stainless steels ${ }^{1}$. The Cobalt-Chromium-Molybdenum (CoCrMo) based alloys are widely used for orthopedic implants and dental skeletal structures, such as screws, pins and plates ${ }^{2-4}$. The CoCrMo alloys are also found in industrial applications, such as wind turbines, engine components and bearings. The advantages of using these alloys are due to their better bulk mechanical properties, in particular their wear resistance and strength combined with corrosion resistance and biocompatibility. The CoCrMo alloys spontaneously form on their surfaces a passive, protective film, mostly $\mathrm{Cr}_{2} \mathrm{O}_{3}$.

Buciumeanu et al. ${ }^{5}$ studied the tribocorrosion behavior of hot pressed CoCrMo alloys in artificial saliva. According to the authors, the degradation of biomaterials is a complex phenomenon, because it operates in a corrosive environment. In fact, the corrosion resistance of a biomaterial is determined by the characteristics of this passive film ${ }^{6}$. Thus, the study of the corrosion resistance of metallic biomaterials is essential, since this is one of the key factors that determines their biocompatibility. The release of the toxic metallic ions can lead to various adverse tissue reactions and/or hypersensitivity reactions ${ }^{7}$. The uniform passive dissolution resulted from the slow diffusion of metal ions through the passive film, and the local breakdown of the passivity as a consequence of the various types of localized corrosion, or various mechanical events, such as fretting corrosion ${ }^{8-11}$.

Despite their applications in orthopedics, which are mainly based on their corrosion resistance, the electrochemical properties of CoCrMo alloys have not been extensively investigated until now, having been considered scarce in literature ${ }^{6,12-22}$. According to Bettini et al. ${ }^{23}$, many works have been focused on the influence of the microstructure on the wear and mechanical properties of CoCrMo alloy. However, little is known about its influence on the corrosion behavior of CoCrMo alloy. 
Although the quantity of information concerning the electrochemical corrosion resistance and chemical properties of the passive film formed on the CoCrMo biomaterial seems sufficient, there is a certain difficulty in comparing the results from different authors, since the parameters in which the experiments were conducted vary, such as with temperature, electrolyte composition, time of immersion and potential in which the electrochemical measurements were done. The present research was aimed at characterizing CoCrMo alloy by electrochemical methods, to understand the effect of the electrolyte composition, temperature and immersion time on the corrosion resistance of this material. The electrochemical studies were carried out in presence of Hank's and physiological serum solutions $(0.9 \mathrm{wt} \% \mathrm{NaCl})$ at two temperatures $\left(25\right.$ and $37^{\circ} \mathrm{C}$.) The Electrochemical properties of the CoCrMo alloy were characterized using open circuit potential (OCP) measurements, potentiodynamic polarization curves (PPC) and electrochemical impedance spectroscopy (EIS).

\section{Materials and Methods}

\subsection{Chemical composition}

For the present investigations, the CoCrMo alloy (donated by MDT Ltda) was used in the following conditions. Table 1 lists the chemical composition of the major elements.

\subsection{Electrochemical measurements}

\subsubsection{Open circuit potential and potentiodynamic polarization}

Standard electrochemical corrosion procedures were followed. The tests began with an open circuit potential (OCP), in which the corrosion potential $\left(E_{\text {corr }}\right)$ of the samples was monitored during $7 \mathrm{~h}$, in the presence of physiological serum and Hank's solution. Potentiodynamic polarization followed the ASTM G61 standard, and the measurements were made in the range $-50 \mathrm{mV}$, to show the potential in which the anodic current was $500 \mu \mathrm{A}$, with a potential sweep rate of $2.5 \mathrm{mV} \mathrm{s}^{-1}$, using a potentiostat/galvanostat from AUTOLAB ${ }^{\circledR}$ (Eco Chemie, The Netherlands), model PGSTAT10, and the software GPES ${ }^{\circledR}$ (General Purpose Electrochemical System.) The measurements were taken at specific immersion times of $5 \mathrm{~min}$ and $168 \mathrm{~h}$, using an aerated physiological serum $(0.9 \mathrm{wt} \% \mathrm{NaCl})$ and Hank's solution ( $\mathrm{pH}$ 7.5.) To summarize, the samples were mechanically polished using abrasive papers from $320^{\#}$ to $4000^{\#}$ prior to electrochemical corrosion testing. After, the samples were degreased with propanol and cleaned carefully with distilled water.

\subsubsection{Electrochemical impedance spectroscopy tests}

Electrochemical impedance spectra (EIS) were obtained for CoCrMo alloy using the same solution as described before, in the frequency range of $65 \mathrm{kHz}$ to $10 \mathrm{mHz}$, using a sinusoidal perturbation of $10 \mathrm{mV}$ (rms.) All the above electrochemical experiments were conducted using a classical three-electrode configuration: the CoCrMo alloy as working electrode with an exposed area of $0.785 \mathrm{~cm}^{2}, \mathrm{a} \mathrm{Ag} / \mathrm{AgCl} / \mathrm{KCl}$, $\mathrm{AgCl}$ (sat.) as reference electrode and a platinum auxiliary electrode. A thermostatic bath from Tecnal ${ }^{\circledR}$, model TE2005 , was used to maintain the desired temperature. The reference electrode was kept at $\sim 4 \mathrm{~mm}$ from the sample, in order to minimize the ohmic drop. For EIS data fitting, the Equivcrt ${ }^{\circledR}$ software was used ${ }^{24-25}$. To ensure linearity of the electrode response, a small amplitude sine wave $(5 \mathrm{mV}$ $(\mathrm{p} / \mathrm{p}))$ was used throughout the experiment.

\section{Results and Discussion}

\subsection{Open circuit potential (OCP) and Potentiodynamic Polarization Curves (PPC)}

The OCP measurements were carried out on the CoCrMo alloy as a function of immersion time, in the presence of physiological serum $(0.9 \mathrm{wt} \% \mathrm{NaCl})$ and Hank's solution $(\mathrm{pH} 7.5)$, at temperatures of 25 and $37^{\circ} \mathrm{C}$, as shown in Figure 1.

Comparing the corrosion potential $\left(E_{\text {corr }}\right)$ for both solutions, it is possible to verify that the Hank's solution presented values more negative for the two temperatures studied, indicating a greater susceptibility to the corrosion process as described by Moreto et al. ${ }^{26}$. It is important to note that in the presence of the physiological serum solution at $37{ }^{\circ} \mathrm{C}$, the CoCrMo alloy presented transient currents, indicating a competition between the anodic and cathodic regions. The difference in composition between the depleted chromium and the matrix compositions leads to a difference in the corrosion potentials that affected the dissolution of the CoCrMo alloy ${ }^{27}$.

Figures 2 and 3 show the PPC curves of CoCrMo alloy, in the presence of physiological serum and Hank's solutions, respectively.

The PPC curves (Figures 2 and 3) for CoCrMo alloy were performed after $5 \mathrm{~min}$ and $168 \mathrm{~h}$ of immersion, at 25

Table 1. Chemical composition (wt $\%$ ) of the CoCrMo alloy

\begin{tabular}{|c|c|c|c|c|c|c|c|c|c|c|}
\hline $\mathrm{Cr}$ & Mo & $\mathrm{Si}$ & $\mathrm{Mn}$ & $\mathrm{Fe}$ & $\mathrm{Ni}$ & $\mathrm{C}$ & $\mathrm{N}$ & $\mathrm{W}$ & $\mathrm{Al}$ & $\mathrm{Ti}$ \\
\hline \multirow[t]{2}{*}{$27.00-30.00$} & $5.00-7.00$ & 1.00 & 1.00 & 0.75 & 0.50 & 0.35 & 0.25 & 0.20 & 0.10 & 0.10 \\
\hline & & & & & alance & & & & & \\
\hline
\end{tabular}




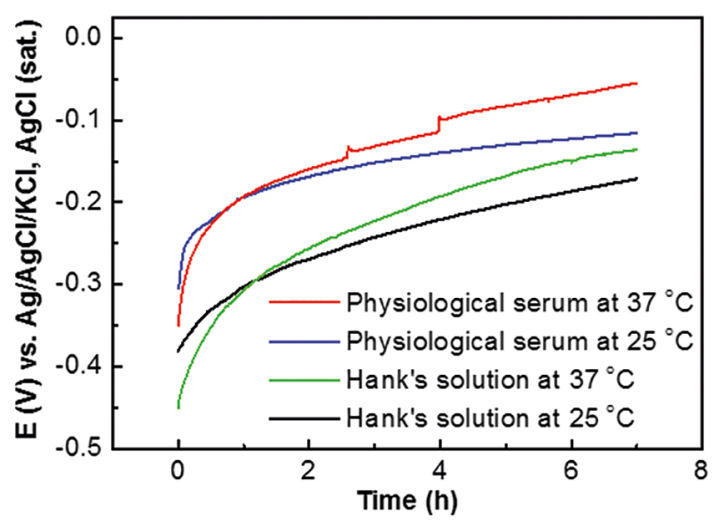

Figure 1. Influence of temperature on open circuit potential measurements, as a function of time for physiological serum and Hank's solution.
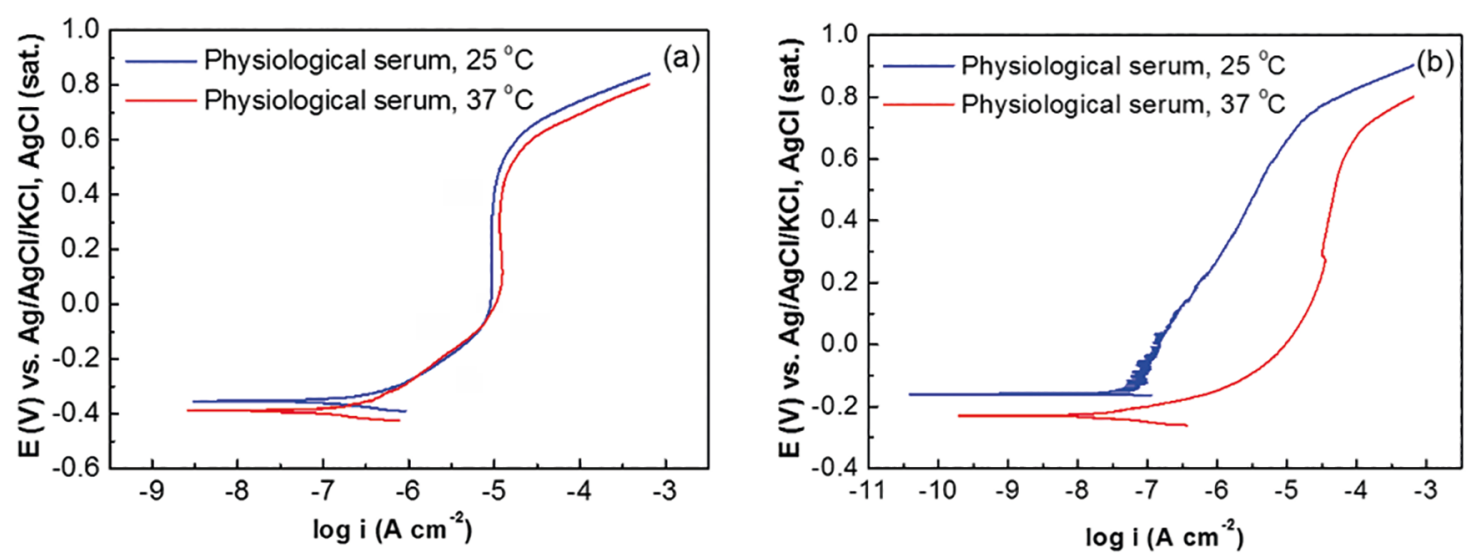

Figure 2. Potentiodynamic polarization curves of CoCrMo in physiological serum, as a function of immersion time, at (a) $5 \mathrm{~min}$ and (b) $168 \mathrm{~h}$, at $25^{\circ} \mathrm{C}$ and $37^{\circ} \mathrm{C}$.
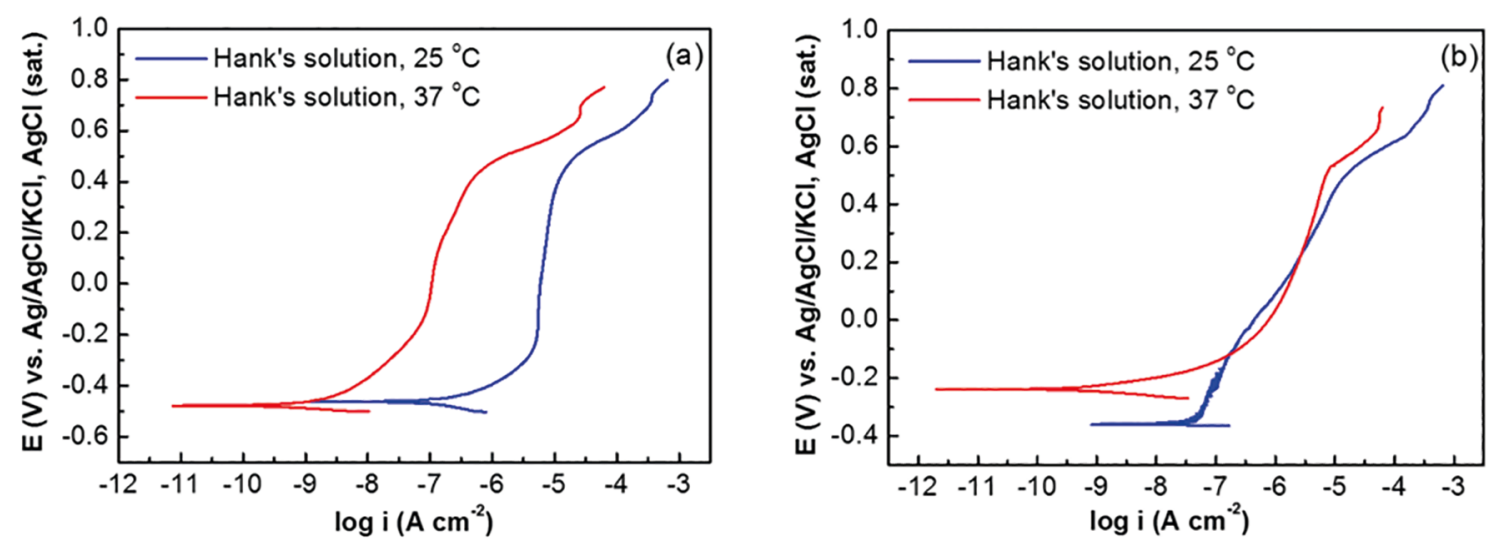

Figure 3. Potentiodynamic polarization curves of CoCrMo in Hank's solution, as a function of immersion time, at (a) 5 min and (b) $168 \mathrm{~h}$, at $25^{\circ} \mathrm{C}$ and $37^{\circ} \mathrm{C}$. 
and $37{ }^{\circ} \mathrm{C}$, for both solutions. All experiments in this study were repeated at least three times to ensure reproducibility. As was seen in the PPC curves, there was a region of passive film formation that appeared at different immersion times and temperatures.

Table 2 shows the values of $E_{\text {corr }}$ obtained from the PPC curves. Qualitative analysis of the PPC curves shows that the $E_{\text {corr }}$ shifts to less negative values when immersion time increases.

Table 2. Corrosion potential for CoCrMo alloy in the presence of physiological serum and Hank's solution, at $5 \mathrm{~min}$ and $168 \mathrm{~h}$ at different temperatures

\begin{tabular}{lccc}
\hline \multirow{2}{*}{ Immersion time } & \multicolumn{2}{c}{$\boldsymbol{E}_{\text {corr }} / \mathrm{V}$} \\
\cline { 2 - 3 } & $\begin{array}{c}\text { Ehysiological } \\
\text { serum }\end{array}$ & Hank's solution \\
\hline & \multicolumn{3}{c}{$25^{\circ} \mathrm{C}$} \\
$5 \mathrm{~min}$ & -0.35 & & -0.46 \\
$168 \mathrm{~h}$ & -0.16 & -0.36 \\
& & $37^{\circ} \mathrm{C}$ & \\
$5 \mathrm{~min}$ & -0.39 & & -0.48 \\
$168 \mathrm{~h}$ & -0.23 & -0.24 \\
\hline
\end{tabular}

This confirms that changes occurred on the metallic surfaces, as a result of the formation of a protective passive film, which leaves the surfaces more noble with time, or more corrosion resistant. In the physiological serum solution, the $E_{\text {corr }}$ shifted to more negative values with increasing temperature $\left(25\right.$ and $\left.37^{\circ} \mathrm{C}\right)$ and immersion time $(5 \mathrm{~min}$ and $168 \mathrm{~h}$ ), indicating the greater aggressiveness of the medium in the corrosion process. In the Hank's solution, the $E_{\text {corr }}$ comportment with the temperature was opposite of that observed in the physiological serum solution, with no significant change in 5 min of immersion, and moving to less negative values after one week of immersion. It is probably that the D-glucose reagent from Hank's solution composes the passivating film ${ }^{28-29}$.

The CoCrMo alloy presents an extensive potential region where the current remained constant with potential for increase, which corresponds to the passive film formation upon potential application. At potentials higher than $\sim 0.6 \mathrm{~V}$ were observed with an increase in the current density with the potential, for both solutions and temperatures (see Figures 2 and 3). According to Giacomelli et al. ${ }^{30}$, the increase of current is due to transpassivation and oxygen evolution reaction. It is important to note that in $\sim+0.65 \mathrm{~V}$, one oxidation peak was observed in the curves from Hank's solution (see, Figure 3 ). It is likely the oxidation peaks are due to electrochemical reactions involving transitions of chromium to high oxidation states, as described by Giacomelli et al. ${ }^{30}$. The electrolyte composition shows influence on the electrochemical corrosion behavior of the CoCrMo alloy.
The passivation current, $i_{\text {pass }}$, was measured for CoCrMo alloy at specific potentials of $+0.2 \mathrm{~V}$ (in physiological serum, at 25 and $37^{\circ} \mathrm{C}$ ) and $+0.1 \mathrm{~V}$ (in Hank's solution, at 25 and $37^{\circ} \mathrm{C}$ ) in $5 \mathrm{~min}$ and $168 \mathrm{~h}$. These potential values are localized in the passive range of the potentiodynamic polarization. Figures 4 (a) and 4 (b) show $i_{\text {pass }}$ as a function of immersion time for CoCrMo alloy, at both temperatures and in presence of physiological serum and Hank's solution, respectively. At $25^{\circ} \mathrm{C}$, the $i_{\text {pass }}$ values decrease as function of time, indicating a more protective passive film. In physiological serum, the highest $i_{\text {pass }}$ values at $37^{\circ} \mathrm{C}$ evidenced the formation of a less stable passive film. The different behavior of $i_{\text {pass }}$ in Hank's solution may be related to the competitiveness between a possible film of D-glucose and oxides of the alloy metals. At $5 \mathrm{~min}$, the D-glucose film better protects the surface at $37^{\circ} \mathrm{C}$, inhibiting metal corrosion. At the time of $168 \mathrm{~h}$, the disruption of the D-glucose film occurs, exposing the metal surface to the dissolution process.

\subsection{Electrochemical impedance spectroscopy measurements (EIS)}

Impedance spectra for CoCrMo alloy at two different immersion times (5 $\mathrm{min}$ and $168 \mathrm{~h}$ ) and two different temperatures $\left(25\right.$ and $37^{\circ} \mathrm{C}$ ) are presented in Figures 5 to 8 , in physiological serum and Hank's solutions, respectively (Nyquist diagram and Bode plots).

The semicircles in the Nyquist diagram find the centers of origin displaced, relative to the real axis, which indicates a situation of "depression," indicating the irregular characteristics of the surface of the CoCrMo alloy. Regarding the Bode diagrams, it is possible to observe two time constants for 168 $\mathrm{h}$ of immersion, while for the immersion time of $5 \mathrm{~min}$, the two time constants are superimposed. In both time constants, the irregular surfaces of the CoCrMo alloy cause a phase angle of less than $-90^{\circ}$.

The equivalent circuit depicted in Figure 9 was proposed to describe the behavior of this kind of material.

The components of this equivalent circuit are: $R_{\Omega}$, ohmic resistance of the electrolyte, and the loop $Q_{f}-R_{f}$, respectively, the capacitance and resistance of the oxide layer and the $Q_{d l}-R_{c t}$ network that represents the charge transfer reactions corresponding to localized corrosion and the capacitance of the double layer. The Impedance spectra were fitted to this circuit, resulting in a very good correlation. Tables 3 and 4 provide the typical values of the fitting results parameters for CoCrMo alloy under different electrolyte compositions, different immersion times and different temperatures.

As is observed, the $R_{\Omega}$ remains more or less constant. As reported by Moreto et al. ${ }^{26}$, the $R_{\Omega}$ depends on the distance between the working and the reference electrodes, which was kept constant in this survey, and on the solution concentration, which is not expected to change within the short duration of the immersion tests. However, it is important to note that all resistance values decreased with increasing temperature, regardless of the electrolyte used. 

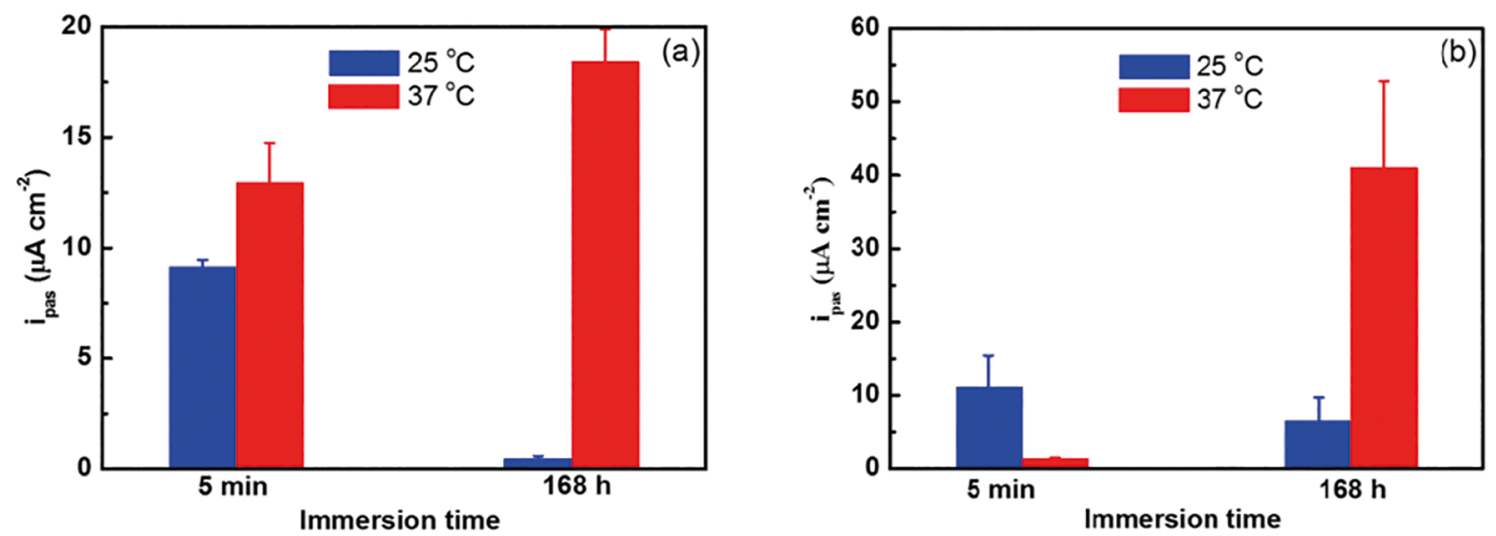

Figure 4. Current passivation, $i_{\text {pass }}$, values of $\mathrm{CoCrMo}$, as a function of immersion time, at $25^{\circ} \mathrm{C}$ and $37^{\circ} \mathrm{C}$. (a) Physiological serum and (b) Hank's solution.
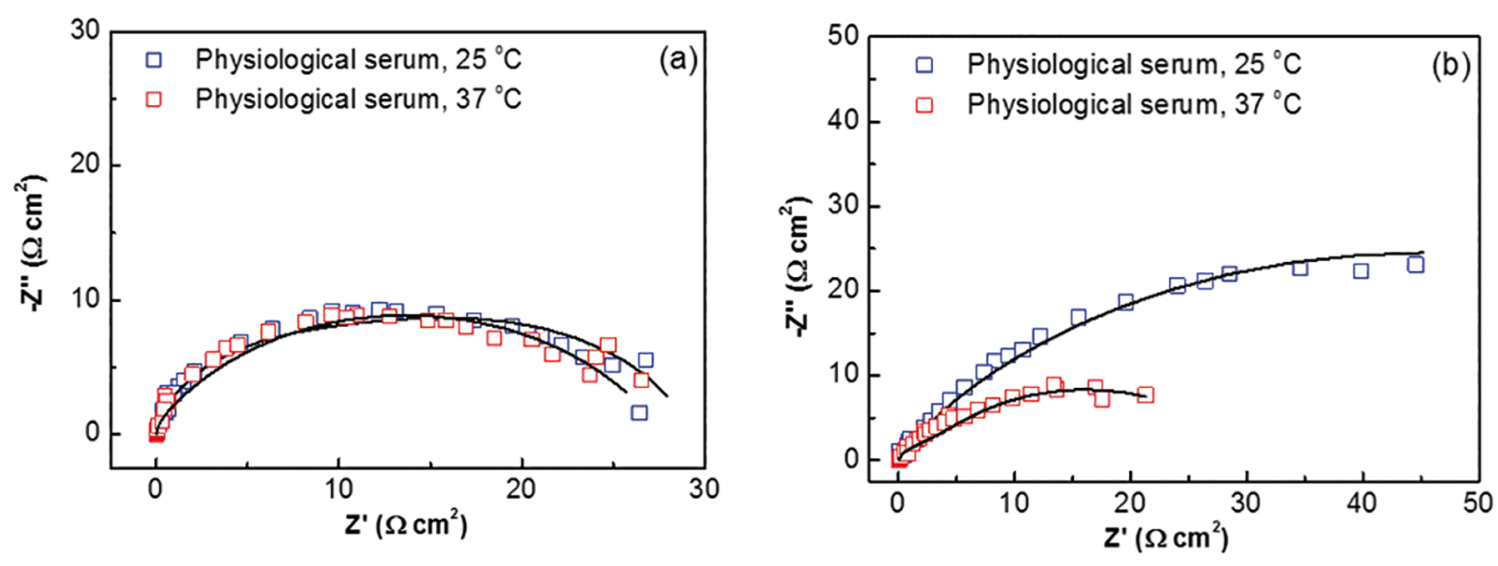

Figure 5. Nyquist diagram of CoCrMo alloy in physiological serum, as a function of immersion time, at (a) 5 min and (b) $168 \mathrm{~h}$, at $25^{\circ} \mathrm{C}$ and $37^{\circ} \mathrm{C}$. The black line represents the fitting obtained by using the electric circuit.
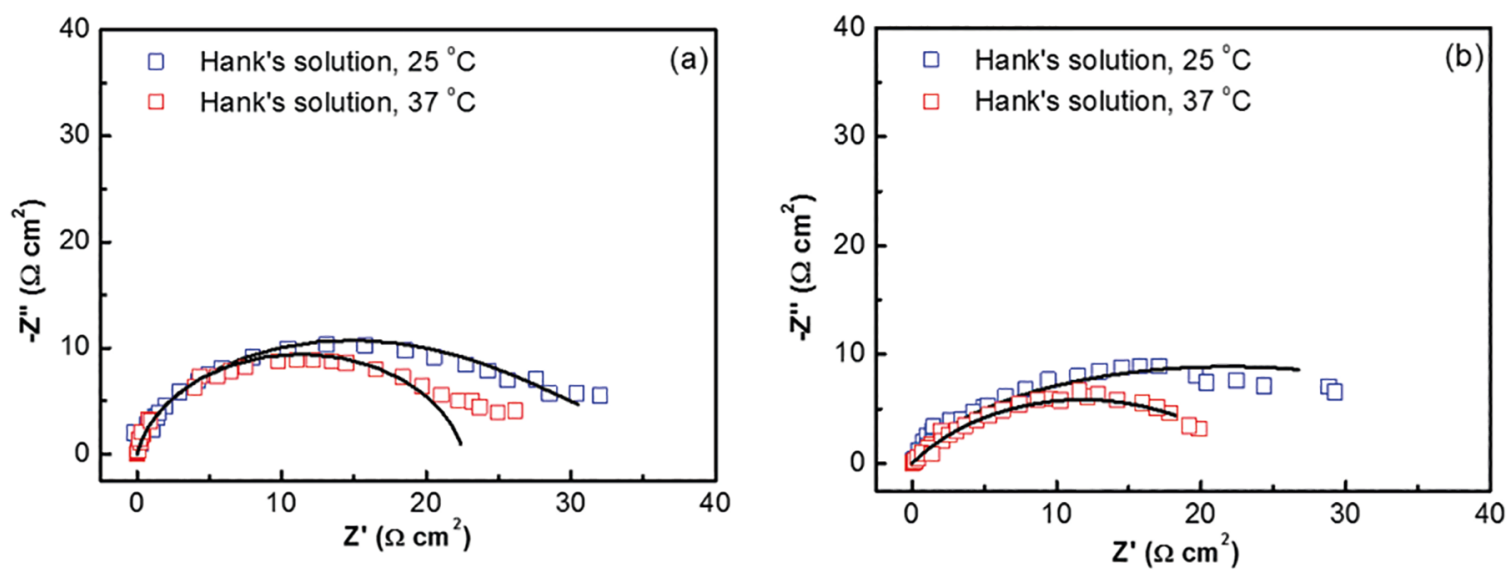

Figure 6. Nyquist diagram of CoCrMo alloy in Hank's solution, as a function of immersion time, at (a) 5 min and (b) $168 \mathrm{~h}$, at $25^{\circ} \mathrm{C}$ and $37^{\circ} \mathrm{C}$. The black line represents the fitting obtained by using the electric circuit. 

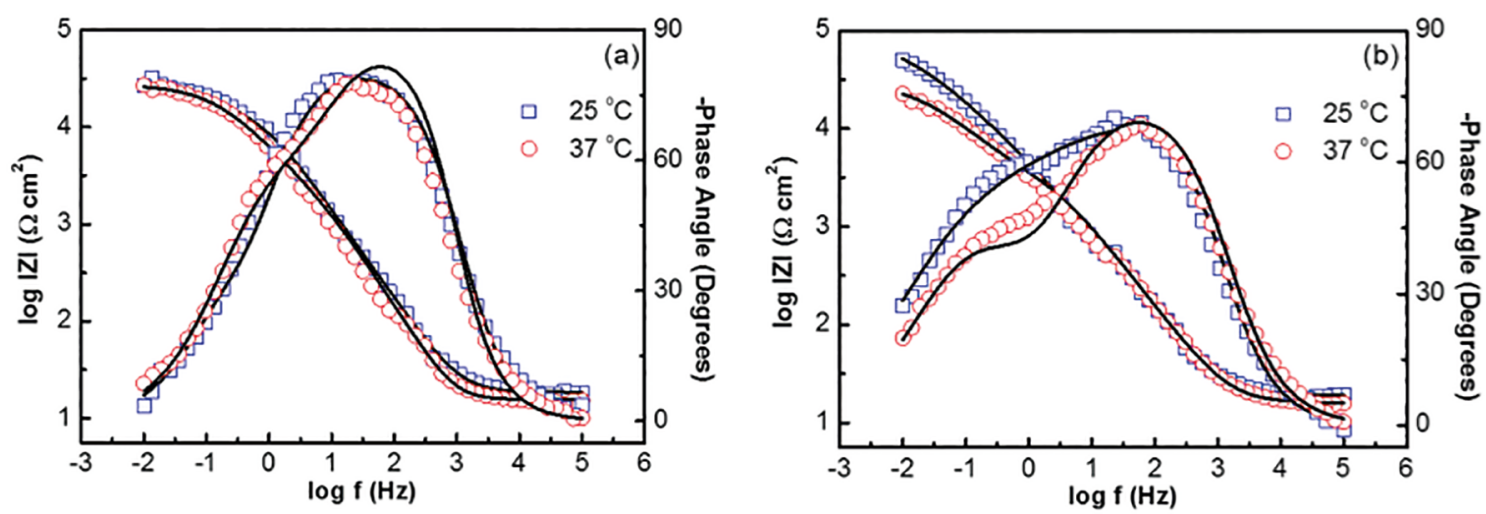

Figure 7. Bode-phase and Bode-magnitude spectra of CoCrMo alloy, in physiological serum, as a function of immersion time, at (a) $5 \mathrm{~min}$ and (b) $168 \mathrm{~h}$, at $25^{\circ} \mathrm{C}$ and $37^{\circ} \mathrm{C}$. The black line represents the fitting obtained by using the electric circuit.
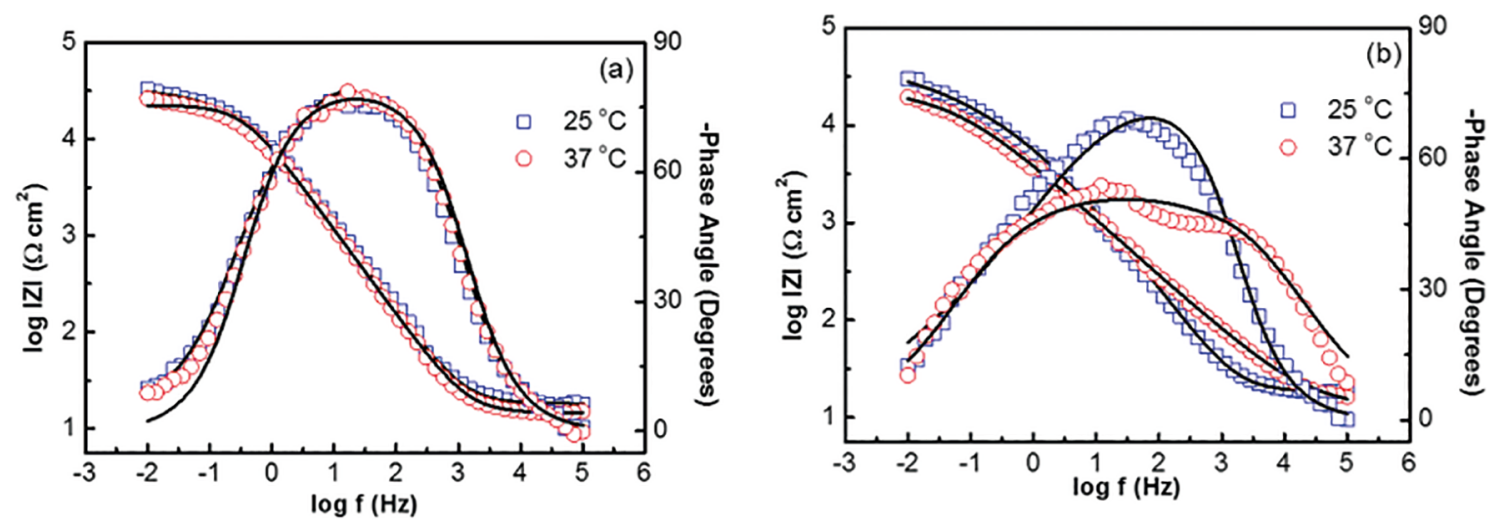

Figure 8. Bode-phase and Bode-magnitude spectra of CoCrMo alloy, in Hank's solution, as a function of immersion time, at (a) 5 min and (b) $168 \mathrm{~h}$, at $25^{\circ} \mathrm{C}$ and $37^{\circ} \mathrm{C}$. The black line represents the fitting obtained by using the electric circuit.

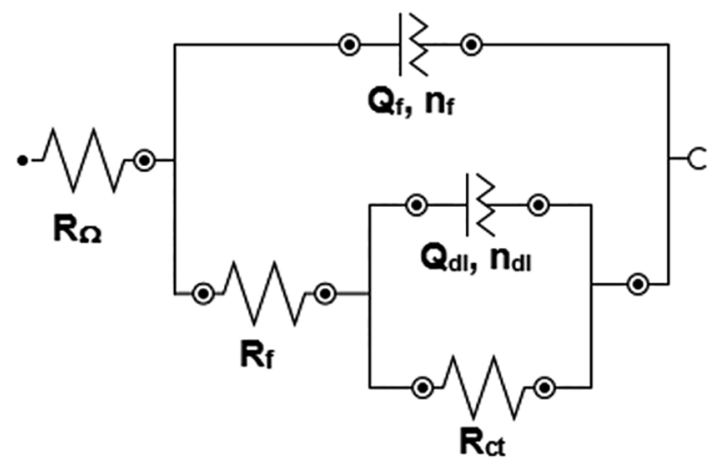

Figure 9. Equivalent circuit used for modeling the $\mathrm{CoCrMo} /$ solution: $\left[\mathrm{R}_{\Omega}\left(\mathrm{Q}_{\mathrm{f}}\left[\mathrm{R}_{\mathrm{f}}\left(\mathrm{Q}_{\mathrm{dc}} \mathrm{R}_{\mathrm{ct}}\right)\right]\right)\right]$

Comparing the results for all conditions, $Q_{f}$ values tend to increase with the immersion time. The increase of $Q_{f}$ with the immersion time at the two temperatures represents the better organization and greater stability of the oxide film formed on the surface of the CoCrMo alloy as described by equation (1):

$$
Q_{f}=\frac{\varepsilon \varepsilon_{0} A}{d}
$$

where $\varepsilon_{0}$ is the vacuum permittivity $(8.85 \mathrm{pF} / \mathrm{m}), A$ is the sample surface area, $d$ is the thickness and $\varepsilon$ is the dielectric constant ${ }^{26}$. The dielectric constant of chromium oxide and iron oxide is approximately $12^{31}$. With regard to aluminum alloys, the dielectric constant is 9 for the dry oxide layer (lower bound) and 40 for a partially hydrated layer (upper bound) ${ }^{32}$. The dielectric constant of the passive film $(\sim 60)^{33}$ for titanium dioxide $\mathrm{TiO}_{2}$ and $\sim 25$ for tantalum pentoxide $\left(\mathrm{Ta}_{2} \mathrm{O}_{5}\right)^{34}$.

Analyzing the values of $Q_{f}$ at $25{ }^{\circ} \mathrm{C}$ as a function of immersion time, it is possible to verify that physiological serum solution presents a smaller variation $(\sim 17.87 \%)$ when comparing to the Hank's solution. However, the opposite effect was observed at $37^{\circ} \mathrm{C}$. This anomalous behavior may be explained due to D-glucose film formation and subsequent adsorption instability on the surface of the CoCrMo alloy, as already discussed before.

The values of $Q_{d l}$ shows a tendency towards higher values, with the immersion time for the physiological serum and Hank's solution at 25 and $37{ }^{\circ} \mathrm{C}$. According to equation (2), the increase of $Q_{d l}$ may be associated with the real area where the corrosion process is taking place. The dominant corrosion protection in all CoCrMo alloys is a thin film of 
Table 3. Fitting parameters obtained from the average of three impedance measurements for CoCrMo alloy, in presence of physiological serum at $5 \mathrm{~min}$ and $168 \mathrm{~h}$

\begin{tabular}{|c|c|c|c|c|c|c|c|}
\hline Temperature & $\begin{array}{c}R_{\Omega} \\
\left(\Omega \mathrm{cm}^{2}\right)\end{array}$ & $\begin{array}{c}R_{f} \\
\left(\mathrm{k} \Omega \mathrm{cm}^{2}\right)\end{array}$ & $\begin{array}{c}Q_{f} \\
\left(\mu \mathrm{F} \mathrm{cm}^{-2}\right)\end{array}$ & $n_{f}$ & $\begin{array}{c}R_{c t} \\
\left(\mathrm{k} \Omega \mathrm{cm}^{2}\right)\end{array}$ & $\begin{array}{c}Q_{d l} \\
\left(\mu \mathrm{F} \mathrm{cm}^{-2}\right)\end{array}$ & $n_{d l}$ \\
\hline & \multicolumn{7}{|c|}{ Immersion time: $5 \mathrm{~min}$} \\
\hline $25^{\circ} \mathrm{C}$ & 18.42 & 1.77 & 12.81 & 0.97 & 30.68 & 38.96 & 0.57 \\
\hline \multirow[t]{2}{*}{$37^{\circ} \mathrm{C}$} & 15.75 & 1.74 & 16.32 & 0.94 & 22.90 & 40.07 & 0.65 \\
\hline & \multicolumn{7}{|c|}{ Immersion time: $168 \mathrm{~h}$} \\
\hline $25^{\circ} \mathrm{C}$ & 18.70 & 3.50 & 23.21 & 0.89 & 63.26 & 46.08 & 0.73 \\
\hline $37^{\circ} \mathrm{C}$ & 15.18 & 2.87 & 28.94 & 0.85 & 26.60 & 95.44 & 0.68 \\
\hline
\end{tabular}

Table 4. Fitting parameters obtained from the average of three impedance measurements for CoCrMo alloy, in presence of Hank's solution, at $5 \mathrm{~min}$ and $168 \mathrm{~h}$

\begin{tabular}{|c|c|c|c|c|c|c|c|}
\hline Temperature & $\begin{array}{c}R_{\Omega} \\
\left(\Omega \mathrm{cm}^{2}\right)\end{array}$ & $\begin{array}{c}R_{f} \\
\left(\mathrm{k} \Omega \mathrm{cm}^{2}\right)\end{array}$ & $\begin{array}{c}Q_{f} \\
\left(\mu \mathrm{F} \mathrm{cm}^{-2}\right)\end{array}$ & $n_{f}$ & $\begin{array}{c}R_{c t} \\
\left(\mathrm{k} \Omega \mathrm{cm}^{2}\right)\end{array}$ & $\begin{array}{c}Q_{d l} / \\
\left(\mu \mathrm{F} \mathrm{cm}^{-2}\right)\end{array}$ & $n_{d l}$ \\
\hline & \multicolumn{7}{|c|}{ Immersion time: $5 \mathrm{~min}$} \\
\hline $25^{\circ} \mathrm{C}$ & 18.41 & 5.72 & 17.65 & 0.92 & 85.96 & 27.96 & 0.62 \\
\hline \multirow[t]{2}{*}{$37^{\circ} \mathrm{C}$} & 14.46 & 5.16 & 22.39 & 0.91 & 57.68 & 31.74 & 0.72 \\
\hline & \multicolumn{7}{|c|}{ Immersion time: $168 \mathrm{~h}$} \\
\hline $25^{\circ} \mathrm{C}$ & 17.86 & 5.93 & 27.00 & 0.81 & 64.80 & 67.79 & 0.69 \\
\hline $37^{\circ} \mathrm{C}$ & 14.48 & 0.94 & 16.29 & 0.73 & 15.63 & 76.19 & 0.60 \\
\hline
\end{tabular}

chromium oxide $\left(\mathrm{Cr}_{2} \mathrm{O}_{3}\right)$. As this alloy corrodes, the mass loss of material is not constant; there is often preferential corrosion $^{28}$. The analysis of $R_{c t}$ values on the CoCrMo alloy shows a tendency towards lower values as the immersion time increases. These results are in agreement with the increase of $Q_{d l}$ values. As can be seen, the $R_{c t}$ values are always higher for the physiological serum solution at 25 and $37^{\circ} \mathrm{C}$, indicating a better performance than Hank's solution in the same condition of tests, see Figure 10.

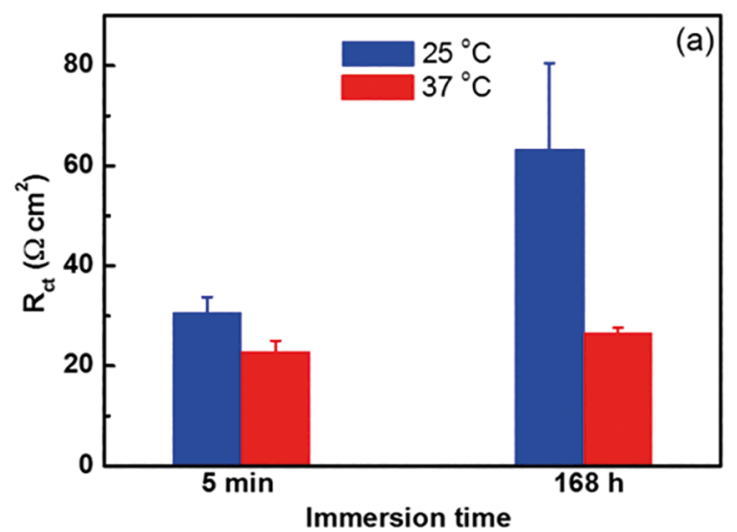

For the CoCrMo alloy in presence of the Hank's solution, no clear treads were observed for the $R_{c t}$ values, as described by equation (3), exhibiting that the corroded area $\left(A_{\text {corroded }}\right)$ is increasing for both temperatures. This phenomenon probably has a relation with the formation of a porous film and with the adsorption of ions. The variables presented in equations 2 and 3 are: corroded area $\left(A_{\text {corroded }}\right)$, geometric area $\left(A_{\text {geom }}\right), Q_{d l}{ }^{*}-R_{c t}{ }^{*}$ network that represents the apparent charge transfer reactions corresponding to localized corrosion and the capacitance of the double layer.

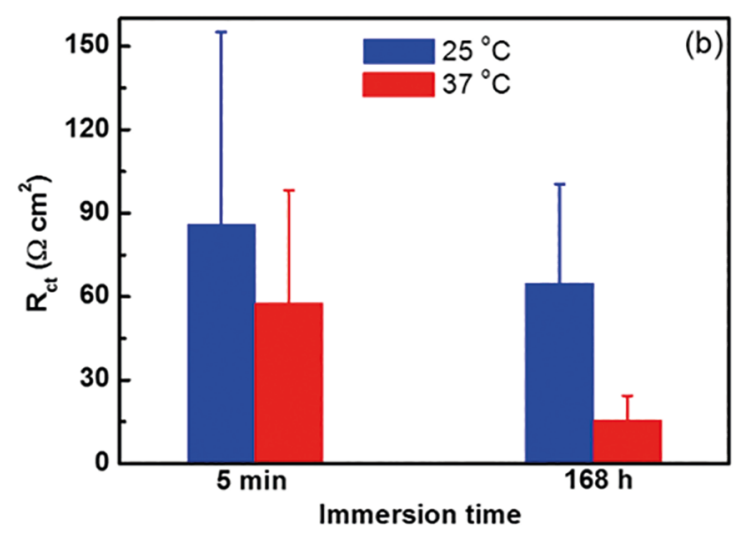

Figure 10. Charge transference resistant, $R_{c t}$, values of $\mathrm{CoCrMo}$, as a function of immersion time, at $25^{\circ} \mathrm{C}$ and $37^{\circ} \mathrm{C}$. (a) Physiological serum; (b) Hank's solution 


$$
\begin{aligned}
Q_{d l} & =Q_{d l}^{*} \frac{A_{\text {corroded }}}{A_{\text {geom }}} \\
R_{c t} & =R_{c t}^{*} \frac{A_{\text {geom }}}{A_{\text {corroded }}}
\end{aligned}
$$

It was possible to verify that the increase in temperature facilitates the removal of D-glucose on the surface of the CoCrMo alloy. It is believed that the increase in temperature caused a rupture of the formed oxide film and facilitated the charge transfer process. This presents a situation in which, the electrolyte composition is shown to influence the electrochemical corrosion behavior of the CoCrMo alloy. The EIS results suggest that the formed film in presence of physiological serum solution is nobler than Hank's solution.

\section{Conclusions}

In the present work, we studied the corrosion behavior of CoCrMo alloy and the effect of temperature, electrolyte composition and immersion time, using electrochemical techniques (open circuit potential, potentiodynamic polarization and electrochemical impedance spectroscopy). It is possible to verify that the corrosion behavior of CoCrMo alloy is influenced by electrolyte composition and temperature. It was shown that the passive films were more protective when formed in the presence of physiological serum. The increase in temperature facilitates the removal of D-glucose on the surface of the CoCrMo alloy for the Hank's solution, creating a rupture of the formed oxide film, and facilitating the charge transfer process. This presents a situation in which, the EIS results show that the formed film, in the presence of physiological serum solution, is nobler than Hank's solution. The $R_{c t}$ values had an inverse behavior when it came to the increase of the immersion time for the solutions of serum and Hank. The decrease of $R_{c t}$ values for Hank's solution is probably due to the formation of a porous film of D-glucose on the surface of the material, allowing greater charge transfer. These results corroborate the $i_{\text {pass }}$ values. As regards the physiological serum solution, the values of $R_{c t}$ increased with the immersion, indicating the formation of a more protective film to the corrosion process.

\section{Acknowledgments}

Financial support from Projects and Studies Financing Institution (FINEP) (process 01.06.0243.00) and Foundation for Research Support of Minas Gerais (FAPEMIG) (processes CDS 12/03 and CEX 1736/06). This work is a collaboration research project of members of the Rede Mineira de Química (RQ-MG), supported by FAPEMIG (project: REDE-113/10 and project: CEX - RED-00010-14) and the National Council for Scientific and Technological Development (CNPq).
Conflict of interest: The authors declare that they have no conflict of interest.

\section{References}

1. Ba DC, Xu L, Wang Q. Effects of plasma nitriding ion beam flux density and time on the properties of CoCrMo alloy. Vacuum. 2015;119:214-222. DOI: 10.1016/j.vacuum.2015.05.032

2. Fraker AC. Corrosion of metallic implants and prosthesis devices. In: Korb LJ, Olsen DL, eds. Corrosion Volume 13 - ASM Metals Handbook. $9^{\text {th }}$ ed. Metals Park: ASM International; 1987.

3. Williams DF. The Properties and Clinical Uses of CobaltChromium Alloys. In: Williams DF, ed. Biocompatibility of Clinical Implant Materials. Boca Raton: CRC Press; 1981.

4. Igual Muñoz A, Schwiesau J, Jolles BM, Mischler S. In vivo electrochemical corrosion study of a CoCrMo biomedical alloy in human synovial fluids. Acta Biomaterialia. 2015;21:228-236. DOI: $10.1016 /$ j.actbio.2015.03.008

5. Buciumeanu M, Bagheri A, Souza JCM, Silva FS, Henriques B. Tribocorrosion behavior of hot pressed CoCrMo alloys in artificial saliva. Tribology International. 2016;97:423-430. DOI: 10.1016/j.triboint.2016.02.007

6. Metikoš-Huković M, Pilić Z, Babić R, Omanović D. Influence of alloying elements on the corrosion stability of CoCrMo implant alloy in Hank's solution. Acta Biomaterialia. 2006;2(6):693700. DOI: $10.1016 /$ j.actbio.2006.06.002

7. Wapner KL. Implications of metallic corrosion in total knee arthroplasty. Clinical Orthopaedics and Related Research. 1991;271:12-20.

8. Okazaki Y, Gotoh E. Comparison of metal release from various metallic biomaterials in vitro. Biomaterials. 2005;26(1):11-21. DOI: 10.1016/j.biomaterials.2004.02.005

9. Hanawa T. Metal ion release from metal implants. Materials Science and Engineering: C. 2004;24(6-8):745-752. DOI: 10.1016/j.msec.2004.08.018

10. Lin HY, Bumgardner JD. Changes in the surface oxide composition of Co-Cr-Mo implant alloy by macrophage cells and their released reactive chemical species. Biomaterials. 2004;25(78):1233-1238. DOI: 10.1016/j.biomaterials.2003.08.016

11. Contu F, Elsener B, Böhni H. Corrosion behaviour of CoCrMo implant alloy during fretting in bovine serum. Corrosion Science. 2005;47(8):1863-1875. DOI: 10.1016/j.corsci.2004.09.003

12. Contu F, Elsener B, Böhni H. Electrochemical Behavior of CoCrMo Alloy in the Active State in Acidic and Alkaline Buffered Solutions. Journal of the Electrochemical Society. 2003;150(9):B419-B424. DOI: 10.1149/1.1595660

13. Codaro EN, Melnikov P, Ramires I, Guastaldi AC. Corrosion behavior of a cobaltchromium-molybdenum alloy. Russian Journal of Electrochemistry. 2000;36(10):1117-1121. DOI: 10.1007/BF02757531

14. Özçelik F, Gulen J, Akdoğan A, Pişkin S. Electrochemical study of the corrosion behaviour of Co-Cr-Mo orthopedic implants. Praktische Metallographie. 1999;36:385-391. 
15. Li YS, Wang K, He P, Huang BX, Kovacs P. Surface-enhanced Raman spectroelectrochemical studies of corrosion films on implant Co-Cr-Mo alloy in biosimulating solutions. Journal of Raman Spectroscopy. 1999;30(2):97-103. DOI: 10.1002/ (SICI)1097-4555(199902)30:2<97::AID-JRS352>3.0.CO;2-X

16. Milošev I, Strehblow HH. The composition of the surface passive film formed on CoCrMo alloy in simulated physiological solution. Electrochimica Acta. 2003;48(19):2767-2774. DOI: 10.1016/S0013-4686(03)00396-7

17. Kocijan A, Milošev I, Pihlar B. Cobalt-based alloys for orthopaedic applications studied by electrochemical and XPS analysis. Journal of Materials Science: Materials in Medicine. 2004;15(6):643650. DOI: 10.1023/B:JMSM.0000030204.08616.3d

18. Hodgson AWE, Kurz S, Virtanen S, Fervel V, Olsson COA, Mischler S. Passive and transpassive behaviour of CoCrMo in simulated biological solutions. Electrochimica Acta. 2004;49(13):2167-2178. DOI: 10.1016/j.electacta.2003.12.043

19. Hanawa T, Hiromoto S, Asami K. Characterization of the surface oxide film of a Co-Cr-Mo alloy after being located in quasibiological environments using XPS. Applied Surface Science. 2001;183(1-2):68-75. DOI: 10.1016/S0169-4332(01)00551-7

20. Moore RL, Grobe GL III, Gardella JA. Auger and x-ray photoelectron study of surface heterogeneity in ASTM F-75 alloy prepared for biomedical implantation. Journal of Vacuum Science \& Technology A: Vacuum, Surfaces, and Films. 1991;9(3):1323-1328. DOI: 10.1116/1.577620

21. Lewis G. X-ray photoelectron spectroscopy study of surface layers on orthopaedic alloys. II. Co-Cr-Mo (ASTM F-75) alloy. Journal of Vacuum Science \& Technology A: Vacuum, Surfaces, and Films. 1993;11(1):168-174. DOI: 10.1116/1.578285

22. Reclaru L, Lüthy H, Eschler PY, Blatter A, Susz C. Corrosion behaviour of cobalt-chromium dental alloys doped with precious metals. Biomaterials. 2005;26(21):4358-4365. DOI: 10.1016/j. biomaterials.2004.11.018

23. Bettini E, Eriksson T, Boström M, Leygraf C, Pan J. Influence of metal carbides on dissolution behavior of biomedical CoCrMo alloy: SEM, TEM and AFM studies. Electrochimica Acta. 2011;56(25):9413-9419. DOI: 10.1016/j.electacta.2011.08.028

24. Boukamp BA. A package for impedance/admittance data analysis. Solid State Ionics. 1986;18-19(Pt 1):136-140. DOI: $10.1016 / 0167-2738(86) 90100-1$
25. Boukamp BA. A Nonlinear Least Squares Fit procedure for analysis of immittance data of electrochemical systems. Solid State Ionics. 1986;20(1):31-44. DOI: 10.1016/01672738(86)90031-7

26. Moreto JA, Marino CEB, Bose Filho WW, Rocha LA, Fernandes JCS. SVET, SKP and EIS study of the corrosion behaviour of high strength $\mathrm{Al}$ and $\mathrm{Al}-\mathrm{Li}$ alloys used in aircraft fabrication. Corrosion Science. 2014;84:30-41. DOI: 10.1016/j. corsci.2014.03.001

27. Hoffman EE. Tribology and Corrosion in CoCrMo Alloys and Similar Systems. [Dissertation]. Evanston: Northwestern University; 2017.

28. Ali-Shattle EE, Mami MH, Alnaiu MM. Investigation of the Inhibitory Effect of Sucrose on Corrosion of Iron (Libyan Steel) in Mineral Acid Solutions. Asian Journal of Chemistry. 2009;21(7):5431-5437.

29. El-etre AY. Natural honey as corrosion inhibitor for metals and alloys. i. copper in neutral aqueous solution. Corrosion Science. 1998;40(11):1845-1850.

30. Giacomelli FC, Giacomelli C, Spinelli A. Behavior of a CoCr-Mo Biomaterial in Simulated Body Fluid Solutions Studied by Electrochemical and Surface Analysis Techniques. Journal of the Brazilian Chemical Society. 2004;15(4):541-547. DOI: $10.1590 / \mathrm{S} 0103-50532004000400016$

31. Ferreira MGS, da Cunha Belo M, Hakiki NE, Goodlet G, Montemor MF, Simões AMP. Semiconducting Properties of Oxide and Passive Films Formed on AISI 304 Stainless Steel and Alloy 600. Journal of the Brazilian Chemical Society. 2002;13:433-440. DOI: 10.1590/S010350532002000400005

32. Martin FJ, Cheek GT, Grady WE, Natishan PM. Impedance studies of the passive film on aluminium. Corrosion Science. 2005;47(12):3187-3201. DOI: 10.1016/j. corsci.2005.05.058

33. Cheng J, Xu J, Liu LL, Jiang SY. Electrochemical Corrosion Behavior of $\mathrm{Ta}_{2} \mathrm{~N}$ Nanoceramic Coating in Simulated Body Fluid. Materials (Basel). 2016;9(9):772. DOI: 10.3390/ma9090772

34. Jovic VD, Barsoum MW. Corrosion Behavior and Passive Film Characteristics Formed on $\mathrm{Ti}, \mathrm{Ti}_{3} \mathrm{SiC}_{2}$, and $\mathrm{Ti}_{4} \mathrm{AlN}_{3}$ in $\mathrm{H}_{2} \mathrm{SO}_{4}$ and $\mathrm{HCl}$. Journal of the Electrochemical Society. 2004;151(2):B71-B76. 